\title{
Scrotal oedema in a man who had cystoprostatectomy and ileal diversion 9 years ago
}

\author{
Han-Kuang Chen, Dominic Sinagra, Justin Vivian
}

St John of God Subiaco Hospital, Subiaco, Western Australia, Australia

\section{Correspondence to} Dr Han-Kuang Chen, hankuang.chen@gmail.com

Accepted 26 August 2014
CrossMark

\section{To cite: Chen $\mathrm{H}-\mathrm{K}$,} Sinagra D, Vivian J. BMJ Case Rep Published online: [please include Day Month Year] doi:10.1136/bcr-2014206646

\section{DESCRIPTION}

We report a case of an 88-year-old man who presented to his general practitioner with scrotal oedema. He had a history of diabetes, ischaemic heart disease, congestive heart failure, T1G3 transitional cell carcinoma in his bladder and he was treated with cystoprostatectomy and ileal diversion in 2005. It was thought that the scrotal oedema was associated with his congestive heart failure. However, the symptom worsened despite optimisation of his medical management. This patient later on developed right groin lymphadenopathy which was biopsied and showed metastatic squamous cell carcinoma.

Later on it was found by a urologist that the patient had an ulcerative lesion on the urethral meatus which he was unaware of (figure 1). On biopsy, it proved to be squamous cell carcinoma, and bone scan showed extensive metastasis to the right groin lymph nodes, resulting in scrotal lymphoedema (figure 2). One may wonder why this significant penile lesion had not been detected until this late stage. The explanation is that the patient described in this case had cystoprostatectomy and ileal diversion in 2005 and he had not voided through his penis since. As a result, the patient did not notice the penile ulcer under the foreskin and failed to report this to his general practitioner.

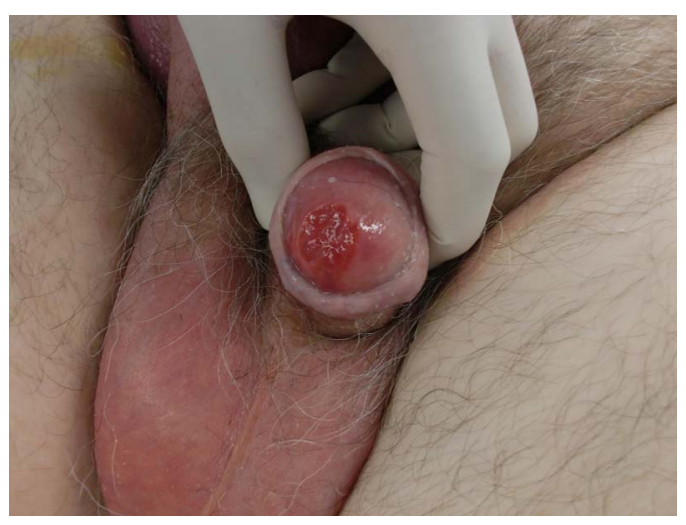

Figure 1 Preoperative photo of the ulcerative lesion on urethral meatus.

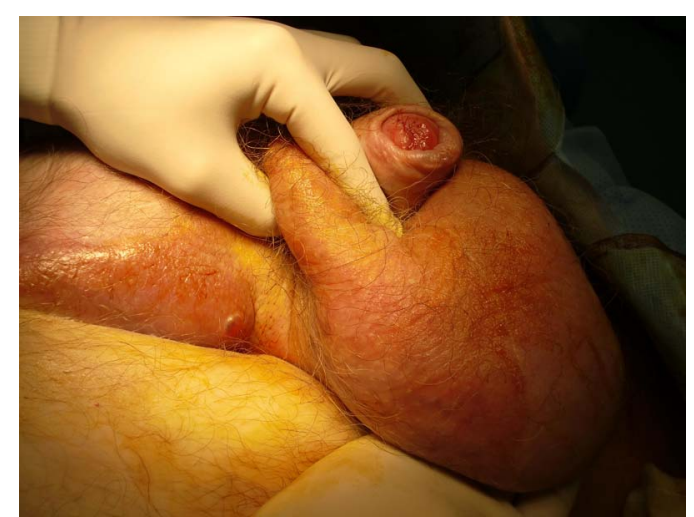

Figure 2 Postbiopsy photo showing scrotal oedema and right groin lymphadenopathy.

\section{Learning points}

- Cancers of the penis most commonly present with a lump or ulcer which is otherwise asymptomatic. ${ }^{1}$

- It is of paramount importance to retract the foreskin to examine the gland penis when performing a genital examination.

- Positive lymph nodes has a detrimental effect on survival.

Contributors $\mathrm{H}-\mathrm{KC}$ and DS contributed by reviewing the patient, assisted in procedure and writing up the case. JV is the treating consultant and supervised the writing up of the case report.

Competing interests None.

Patient consent Obtained.

Provenance and peer review Not commissioned; externally peer reviewed.

\section{REFERENCE}

1 Ritchie A, Foster P, Fowler S. Penile cancer in the UK: clinical presentation and outcome in 1998/99. BJU Int 2004;94:1248-52. 
Copyright 2014 BMJ Publishing Group. All rights reserved. For permission to reuse any of this content visit http://group.bmj.com/group/rights-licensing/permissions.

BMJ Case Report Fellows may re-use this article for personal use and teaching without any further permission.

Become a Fellow of BMJ Case Reports today and you can:

- Submit as many cases as you like

- Enjoy fast sympathetic peer review and rapid publication of accepted articles

- Access all the published articles

- Re-use any of the published material for personal use and teaching without further permission

For information on Institutional Fellowships contact consortiasales@bmjgroup.com

Visit casereports.bmj.com for more articles like this and to become a Fellow 